\title{
DEMATERIALIZATION RETAIL: BOOKSTORE EXPERIENCE IN PHYSICAL AND VIRTUAL DIMENSIONS
}

\author{
Varejo em desmaterialização: Experiência da livraria nas dimensões física e virtual \\ Desmaterialización al por menor: Experiencia de librería en dimensiones físicas y virtuales
}

Maria Silvia Moliterno Pena' ${ }^{1}$ msilviapena@gmail.com | ORCID: 0000-0003-0897-9113

Eliane Pereira Zamith Brito ${ }^{1}$ | eliane.brito@fgv.br | ORCID: 00oo-0002-7340-1337

1Fundação Getulio Vargas Escola de Administração de Empresas de São Paulo, São Paulo, SP, Brazil

\begin{abstract}
The aim of this study is to understand the role and relevance of the physical store in contemporary integrated retail. The literature suggests that a physical store maintains its relevance as a place of experience, but from the consumer's perspective it does not detail what determines relevance and which experiences emerge from the physical store. Based on the concept of experience co-creation, we argue that each consumer's experience is unique, and that the relevance of the store is determined by the consumer's personal characteristics. We identified emergent experiences from both physical and virtual stores and the role of technology in consumer empowerment. As a managerial contribution, our study provides a direction for physical and virtual integrated retail management. We determined that in bookstores, a segment strongly impacted by dematerialization, the characteristics that determine the relevance of the physical store are related to an appreciation of reading and an attachment to materiality. The experiences that emerge from the store are Buying Place, Gold-Digging, Magical Portal and Home Refuge. Although the results are context-specific, they can drive analysis of the dematerialization of retail in general.
\end{abstract}

KEYWORDS | Consumer experience, physical store, virtual store, dematerialization, integrated retail.

\section{RESUMO}

Oobjetivo deste estudo éo entendimento do papel e da relevância da loja física no varejo contemporâneo em processo de desmaterialização. A literatura sugere que a loja física mantém a relevância no varejo integrado como lugar da experiência, entretanto não detalha, pela perspectiva do consumidor, o que determina a relevância e que experiências emergem da loja física. Partindo do conceito de cocriação da experiência por empresa e consumidor, verificamos que a experiência de cada consumidor é única e que a relevância da loja é determinada pelas características pessoais do consumidor. Identificamos os tipos de experiência que emergem da loja física e da loja virtual, e o papel da tecnologia no empoderamento do consumidor. Como contribuição gerencial, nosso estudo fornece subsídios para a gestão do varejo com dimensões física e virtuais integradas. Determinamos que, nas livrarias, segmento fortemente impactado pela desmaterialização, as características pessoais que determinam a relevância da loja física são relacionadas ao apreço pela leitura e apego ao mundo material, e as experiências que emergem da loja são Lugar de Compra, Garimpo, Portal da Magia e Refúgio do Lar. Os resultados são específicos do contexto, mas direcionam a análise da desmaterialização do varejo em geral.

PALAVRAS-CHAVE I Experiência do consumidor, loja física, loja virtual, desmaterialização, varejo integrado.

\section{RESUMEN}

El objetivo de este estudio es comprender el papel y la relevancia de la tienda física en el comercio minorista contemporáneo en proceso de desmaterialización. La literatura sugiere que la tienda física mantiene su relevancia en el retail integrado como lugar de experiencia; sin embargo, no detalla, desde la perspectiva del consumidor, qué determina la relevancia y qué experiencias surgen de la tienda física. Partiendo del concepto de cocreación de la experiencia por empresa y consumidor, verificamos que la experiencia de cada consumidor es única y que la relevancia de la tienda está determinada por las características personales del consumidor. Identificamos los tipos de experiencias que surgen de la tienda física y de la tienda virtual y el papel de la tecnología en el empoderamiento del consumidor. Como aporte gerencial, nuestro estudio proporciona material para la gestión del retail con dimensiones físicas y virtuales integradas. Determinamos que, en las librerías, segmento fuertemente afectado por la desmaterialización, las características personales que determinan la relevancia de la tienda física están relacionadas con el aprecio por la lectura y el apego al mundo material, y las vivencias que emergen de la tienda son Lugar para Comprar, Minería, Portal Mágico y Refugio del Hogar. Los resultados son específicos del contexto, pero dirigen el análisis de la desmaterialización minorista en general.

PALABRAS CLAVE I Experiencia del consumidor, tienda física, tienda virtual, desmaterialización, retail integrado. 


\section{INTRODUCTION}

Contemporary retail is in transformation, due to the integration of its physical and virtual dimensions (Verhoef, Neslin \& Vroomen, 2007; Shankar, Inman, Mantrala, Kelley, \& Rizley, 2011; Verhoef, Kannan \& Inman, 2015), and the possibility of products simply turning into digital information (Denegri-Knott, Watkins, \& Wood, 2013; Lehdonvirta, 2012). In this new reality, the assumption is that physical stores remain relevant as a place of experience (Gensler, Neslin \& Verhoef, 2017; Shankar et al., 2011; Verhoef et al., 2015; Verhoef et al., 2007). However, the significant number of physical stores that have shut down in recent years (Coffman, 2018; Corkery, 2018; Rushe, 2017) indicates the need from the consumer's perspective to better understand the experience that will sustain the relevance of physical stores.

There is abundant consumer experience literature that expands the concept to incorporate the changes brought about by technology. This literature, however, does not detail the in-store experience in the contemporary context of consumer dematerialization. Consequently, we know hardly anything about the differences in the experiences that emerge from the physical and virtual stores, or the factors that determine the relevance of physical stores. Our study explores these issues and contributes to the consumer experience literature as applied to retail.

The study was conducted in the context of bookstores, whose sales and product channel have been dematerialized. It is a qualitative, interpretative and exploratory study, by which we collected data from phenomenological interviews and participant observation. We carried out our analysis across the field of study, using inductive logic and verifying emerging patterns from the data in an iterative process (Gill, 2014; Smith, Flowers \& Larkin, 2009).

We identified four types of experience emerging from consumer interactions with bookstores, determined by these consumers' personal characteristics related to their appreciation of reading and attachment to materiality. As a managerial contribution, our study provides support for book-integrated retail management. Although we cannot generalize (Thompson, Locander \& Pollio, 1989; Tracy 2010), the study's findings may lead to reflections on the consumer experience in other retail segments undergoing dematerialization.

We detail below the theoretical framework of the study, after which we explain the research carried out, and present and discuss its results.

\section{CONSUMER EXPERIENCE}

There are several definitions of consumer-related experience in the academic literature, such as brand experience (Schmitt, 2009), consumer experience (Thompson et al., 1989), customer experience (Pine \& Gilmore, 1998; Schmitt, Brakus \& Zarantonello, 2015), and experiential marketing (Schmitt, 2011), all having a similar understanding: that experience emerges from a consumer's multidimensional, holistic and subjective responses to a company's offerings (Lemon \& Verhoef, 2016). The experience is not designed and controlled by the company, but rather is dependent on the consumers' contribution and is co-created at the points of contact, including the store (Arnould, 2005). A more recent approach considers that in addition to companies and consumers, technology also integrates the relationship that leads to the experience (Kozinets, 2019; Kozinets, Patterson \& Ashman, 2017), creating an assemblage (DeLanda, 2006). We present below historical overview of the Consumer Experience concept, showing the increase in complexity resulting from the incorporation of technology. 
The concept of experience in the marketing literature originates from the acknowledgment that human beings have feelings (Addis \& Holbrook, 2001; Holbrook, 2018; Lemon \& Verhoef, 2016). In the early 1980s, the view of subjectivity-driven consumers (Hirschman \& Holbrook, 1982; Holbrook \& Hirschman, 1982) contrasts with the prevailing view of rationale and objective-driven consumers, based on an economic way of thinking, and establishes the concept of consumer experience as a tool to create value. Although the paper by Holbrook and Hirschman (1982) is referred to as the inaugural text in research into consumer experience (Carù \& Cova, 2003), academic literature has long recorded the importance of the concept (Holbrook, 2000, 2018).

Holbrook and Hirschman (1982) offer an understanding of hedonic consumption by combining cognition with emotions (Babin, Darden \& Griffin, 1994). Experiences were classified as extraordinary or memorable, because they had an emotional meaning that was strong enough to transform a person (Carù \& Cova, 2003). Publications on management used show business (Schmitt et al., 2004) and theater (Pine \& Gilmore, 1999) metaphors to classify companies with experience-driven strategies. Such experiences were shown as a form of differentiation, staged by companies to create an emotional and memorable connection, leading to consumer engagement and value creation, in addition to ensuring profitability (Pine \& Gilmore, 1998, 1999). Show business practices are examples of creating meaningful experiences (Schmitt, Rogers \& Vrostsos, 2004). The academic literature later came to understand that experiences emerge from all consumption events (Holbrook, 2000) and can be extraordinary or ordinary (Schmitt, 2009), positive or negative (Holbrook, 2000, 2018) and may appeal to subjectivity.

Technology has transformed consumption and the consumer experience. Products are reduced to digital information (Lehdonvirta, 2012; Magaudda, 2011), offers are individualized using data intelligence (Aubrey \& Judge, 2012; Linzbach, Inman \& Nikolova, 2019), digital environments offer full virtual experiences (Denegri-Knott \& Molesworth 2010; Denegri-Knott et al., 2013) and technology platforms create new business models (Belk, 2014; Bardhi \& Eckhardt, 2012). Experiences gain increasing importance in such a dematerialized, ephemeral consumption based on access (Bardhi \& Eckhardt, 2017), and academic literature has begun to investigate the impact of consumption dematerialization on consumer experience, which reveals different perceptions (Mardon \& Belk, 2018): consumption mediated by technology energizes experience (Kozinets et al., 2017); the experience provided by virtual spaces is superior (Denegri-Knott \& Molesworth, 2010); and digital products are valued (Mardon \& Belk, 2018). Nevertheless, the value attributed to physical products is greater than the value attributed to their digital substitutes (Atasoy \& Morewedge, 2018).

Recent studies understand experience as the interconnection between humans, objects and machines (Hoffman \& Novak, 2017; Kozinets, 2019; Kozinets et al., 2017) using the logic of assemblage (DeLanda, 2006), and establish that experience also emerges from the interaction between people and technological objects. By investigating the role of smart objects in consumer assemblages, Hoffman and Novak (2017) propose the concept of an assemblage experience, in which all human and non-human components have agency, and from which multiple overlapping experiences emerge, including the experience of consumer assemblage and object assemblage experiences (Hoffman \& Novak, 2017).

As we have seen, the academic literature follows the technological changes that lead to the dematerialization of consumption, identifies the integration of the physical and virtual dimensions of retail, and establishes roles for virtual stores as places of convenience, and for physical stores as places of experience (Verhoef et al., 2015). It does not indicate, however, the types of experiences that emerge from stores and how the relevance of physical stores is established from the consumer's perspective. Our study contributes to this understanding. 


\section{RESEARCH METHODS}

We conducted qualitative methodology research of an exploratory nature, using a phenomenological approach. Such research seeks to understand a phenomenon from a personal experience approach, integrating the perspectives of the study's participants and the interpretations of the researchers (Thompson et al., 1989), while being mindful of the quality criteria of this qualitative research (Tracy, 2010). Both of the study's authors designed the research, analyzed the data, and wrote the paper. As book lovers and bookstore regulars, however, they recognize that their perspectives are not unbiased. The first author collected the data by way of semi-structured interviews and participant observation between March and November 2018.

We selected the bookstore as the context of the research because it is a segment that has been deeply impacted by the dematerialization of consumption, with digital versions of both the shopping channel and the products, and the book consumption journey can be undertaken in different settings that combine both the physical and virtual environments. We visited eight bookstores with different business models, such as single stores and chain stores, stores in shopping malls and on the street, and large and small stores that offer comprehensive catalogues and specialist catalogues. We made specific observations regarding these stores, but decided to select Livraria Cultura in the Conjunto Nacional, in the city of São Paulo, to serve as support for our systematic data collection due to its large physical space, which attracts a diverse audience, provides for several uses, and allows for extended visits. It also belongs to a chain of bookstores with a consolidated digital presence, whose electronic commerce began in 1994 and is currently responsible for almost a third of its sales (Almeida, 2017). The store is the largest in the chain in terms of sales volume and covering 4,300 square meters has both a café and a theater with 168 seats (Livraria Cultura, 2017). In 2017 the chain had 30 physical stores, trading under the Cultura and Fnac brands (Livraria Cultura, 2017, Melo, 2018), but it has been closing unprofitable stores (Giovanelli, 2016) and focusing its efforts on e-commerce. In October 2018 Livraria Cultura underwent a court-supervised reorganization, and its recovery plan provides for a greater focus on e-commerce, with just a few physical stores remaining (Exame, 2018).

Participant observation took place on different days of the week and at different hours during the day to gain a more comprehensive view of the context. We conducted 16 visits with observation targeted at specific areas of the store, and 22 visits to observe the journeys of customers and salespeople inside the store, each of which took 90 minutes, on average. Following the advice of Wallendorf and Belk (1989), we made a conscious effort to look at that which was familiar to us as something new, by observing the physical space, the routes and the posture of customers when walking around the store, browsing bookshelves, leafing through books, talking to salespeople, meeting friends, sitting down for a cup of coffee, reading or using their cell phones. During ourvisits we made photographic records to complement both the description of what we observed, and our reflections, feelings and assumptions thereof (Wallendorf \& Brucks, 1993).

Phenomenological interviews were conducted to capture participants' emotions and worldviews (Arsel 2017; Thompson et al., 1989). The structure of the interviews contained a list of topics that was based on theory, but with freedom to follow the flow of the conversation and explore related subjects. We used snowball recruitment without compensation and conducted the interviews in places suggested by the participants. We recruited new interviewees until the theory was completely covered, forming a heterogeneous group of 33 participants. We asked 13 of the interviewees to undertake a photo-elicitation exercise to show the images that represented their experiences in bookstores; ten of them performed this task. The interviews took 42 minutes, on average, were recorded in audio with the consent of the participants, and later transcribed, for a total of $178 \mathrm{~A} 4$ pages with 
single spacing. To ensure confidentiality, we used pseudonyms that were inspired by the literary universe and chosen, whenever possible, by the participants. The profile of the participants is shown in Table 1 ; in the columns "Appreciation of reading" and "Attachment to the material world", the number of asterisks indicates the intensity of these traits, so the more asterisks, the more intense they are.

Table 1. Participants

\begin{tabular}{|c|c|c|c|c|c|c|c|}
\hline$\#$ & Pseudonym & Literary Reference & $\begin{array}{l}\text { Appreciation } \\
\text { of reading }\end{array}$ & $\begin{array}{l}\text { Attachment } \\
\text { to Materiality }\end{array}$ & Gender & Age & Profession \\
\hline 1 & Alonso & Don Quixote da La Mancha & $\star \star$ & ** & Male & 51 & Administrator \\
\hline 2 & Bento & Dom Casmurro & $\star \star$ & $\star \star \star *$ & Male & 52 & Administrator \\
\hline 3 & Camilo & Camilo Castelo Branco & 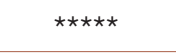 & $\star \star \star \star *$ & Male & 55 & Consultant \\
\hline 4 & Clarice & Clarice Lispector & $\star \star \star \star$ & 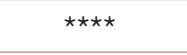 & Female & 23 & Designer \\
\hline 5 & Clarita & Clarita da Pá Virada & 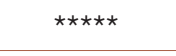 & $\star \star$ & Female & 56 & Book editor \\
\hline 6 & Elizabeth & Pride and prejudice & 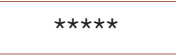 & $\star \star \star \star *$ & Female & 46 & Administrator \\
\hline 7 & Emanuel & Scarred Hearts & $\star \star \star$ & $\star \star \star \star *$ & Male & 51 & Entrepreneur \\
\hline 8 & Emília & Sítio do Pica Pau Amarelo & $\star \star \star \star \star ~$ & 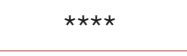 & Female & 53 & Attorney \\
\hline 9 & Fitz & Assassin Creed & $\star \star \star$ & $\star \star$ & Male & 22 & Designer \\
\hline 10 & Helga & O Perfume das Tulipas & 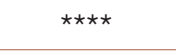 & $\star \star *$ & Female & 55 & Writer \\
\hline 11 & Hermione & Harry Potter & $\star \star \star$ & $\star \star$ & Female & 28 & Consultant \\
\hline 12 & Iracema & José de Alencar & 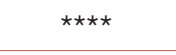 & 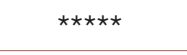 & Female & 69 & Psychotherapist \\
\hline 13 & Ítalo & Ítalo Calvino & $\star \star \star$ & $\star \star \star$ & Female & 27 & Designer \\
\hline 14 & Lucia & The Chronicles of Nárnia & 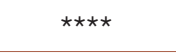 & $\star \star$ & Female & 26 & Advertising Executive \\
\hline 15 & Melanie & Melanie Klein & 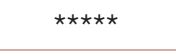 & $\star \star \star *$ & Female & 48 & Psychotherapist \\
\hline 16 & Michael & Millenium Trilogy & $\star \star$ & $\star \star$ & Male & 22 & Designer \\
\hline 17 & Minny & The Help & 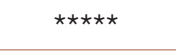 & 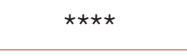 & Female & 47 & Travel Agent \\
\hline 18 & Myron & Harlan Cohen & $\star \star \star \star ~$ & $\star *$ & Female & 30 & Advertising Executive \\
\hline 19 & Narizinho & Sitio do Picapau Amarelo & $\star \star$ & ** & Female & 18 & Student \\
\hline 20 & Nelson & Nelson Rodrigues & $\star \star \star$ & $\star \star \star *$ & Female & 51 & Attorney \\
\hline 21 & Perry & Erle Stanley Gardner & 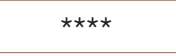 & $\star \star$ & Male & 51 & Physical \\
\hline 22 & Poliana & Poliana & $\star \star \star \star \star *$ & $\star \star \star \star *$ & Female & 50 & Nutritionist \\
\hline 23 & Prince & The Little Prince & $\star \star \star$ & $\star \star \star$ & Male & 27 & Designer \\
\hline 24 & Rubem & A Educação dos Sentidos & 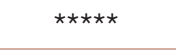 & $\star \star$ & Male & 23 & Psychotherapist \\
\hline 25 & Safira & Eragon & $\star \star *$ & $\star * *$ & Female & 20 & Student \\
\hline 26 & Savannah & Dear John & $\star \star * *$ & $\star \star$ & Female & 28 & Advertising Executive \\
\hline 27 & Sebald & Vertigo & $\star \star$ & ** & Male & 52 & Administrator \\
\hline 28 & Sininho & Peter Pan & $\star \star$ & * & Female & 25 & Designer \\
\hline 29 & Sira & O Tempo Entre Costuras & 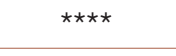 & $\star \star \star \star *$ & Female & 74 & Psychotherapist \\
\hline 30 & Sofia & Sophie's World & $\star \star \star$ & $\star \star \star \star *$ & Female & 18 & Student \\
\hline 31 & Teodora & Invisible Cities & $\star \star \star \star *$ & $\star \star \star *$ & Female & 45 & Advertising Executive \\
\hline 32 & Tistu & $\begin{array}{l}\text { The Boy With The Green } \\
\text { Thumb }\end{array}$ & ** & $\star \star \star \star \star ~$ & Male & 51 & Advertising Executive \\
\hline 33 & Winston & 1984 & ** & * & Male & 53 & Engineer \\
\hline
\end{tabular}

Source: Prepared by the authors 
Data analysis followed an inductive process, with subjects emerging from these data, but without the support of a theoretical structure beforehand; it was carried out throughout the period of the field research. The data collected were analyzed in an iterative process. As the data were collected and transcribed, we analyzed the text to assign codes and identify subject patterns - i.e., categories. We assigned codes to each segment and repeated the process several times. The identification of categories integrated data and theory (Gibbs, 2008; Gill, 2014; Smith, Flowers \& Larkin, 2009; Tracy, 2010). Introspection was used to support data analysis, but not used as data. This is a resource that helps in triangulation to ensure scientific rigor.

\section{RESEARCH FINDINGS}

The retail environment provides multiple experiences (Sherry, 1998), which only take place in the encounter between consumers and company offers, and that materialize at the points of contact (Thompson, 2004). Since the subjectivity of the consumer entails changes, unforeseen events and irrational actions, the co-creation of the experience offers individualized results, as shown by the research findings below. They are organized in two parts: exploring the personal traits that influence experience; and presenting the types of experience that emerge from physical and virtual stores.

\section{Influence of personal traits}

We begin by introducing two different participants. We highlight their preferences regarding reading and the materiality of books and stores in order to situate their experiences in relation to other participants and direct the discussion.

Pollyanna is a nutritionist, a communication studies graduate and a university professor with a Ph.D. She has published three books, one of recipes and two on health. A voracious reader, she reads technical literature because she is obliged to, and novels for leisure. She does not choose bestsellers because she appreciates complex stories that require reflection. Pollyanna loves to discover new bookstores, prefers small ones, but also visits large ones. She spends a lot of time browsing through books, asks sellers for their recommendations, and buys one book at a time. She always buys in physical bookstores, and if a store does not have the book she is looking for, she orders it and goes to the store to get it. Pollyanna never discards any of her books and her living room resembles a library, with books everywhere. She travels frequently, taking several books with her, and recently started using Kindle to carry less weight, although she does not like it and only uses it when traveling. She usually visits bookstores in other countries, but rarely buys foreign books because she prefers to read in Portuguese.

Winston is an engineer and works in the supply area. He frequently visits large bookstores located in shopping centers, and while waiting for his wife to shop also visits sophisticated electronics stores to see what's new. He only reads technical books, which he buys in digital versions over the Internet, although when buying a book as a gift, he purchases the printed version at a physical bookstore. Although visiting a bookstore just to look at books is done without any rush, when his goal is to buy a book as a gift, the visit to the store is quick; he goes directly to the salesperson, picks up the book, pays and leave the place as soon as possible, because he has the impression he is wasting his time. He does not like to keep papers because they turn yellow over time, so he scanned all his diplomas and workbooks he had at home and organized them by topic. This makes it easier 
to access the content, and also makes them more comfortable to read because he can adjust the font size and the background color.

Pollyanna and Winston's personal characteristics lead to different bookstore experiences and opposite extremes in the perception of the relevance of physical stores; Pollyanna finds physical bookstores to be essential, while Winston finds them expendable. Our study shows that the combination of two specific personal characteristics defines the perception of the relevance and role of physical bookstores for each consumer: an appreciation of reading and attachment to materiality. The research participants display these characteristics in varying intensities (see Table 1), in a continued appreciation of reading that varies from passionate to indifferent readers (the study does not include non-reader participants), and a continued attachment to materiality that varies from strongly attached to detached from the physical world.

Passionate readers are research participants who, like Pollyanna, consider reading to be a fundamental part of their identities, are proud of their condition as readers, always carry a book with them, and are very fond of visiting bookstores. While waiting for one of the participants for their interview at the Livraria Cultura cafe, the first author observed a man standing near a bookshelf, leafing through a book and holding three others under his arm. A few minutes after the interview was due to start, he rushed to the counter, bought four books, went to the cafe, introduced himself as the interviewee and offered one of the books to the researcher as a gift, while apologizing for the delay, saying he was unable to go into a bookstore without buying any books. The researcher's notes stated that even before starting the interview she knew Camilo would be a passionate reader.

Indifferent readers are participants who, like Winston, establish a more utilitarian relationship with the act of reading, read mainly to become informed or acquire technical information, and for whom the pleasure does not come from reading itself, but from the knowledge that reading provides. The six participants in this group say they have little time to read, as Tinker Bell explains: "Currently, it is difficult to include [reading] in my routine. Without even realizing it, I'm on Netflix, or tired and go to sleep, so the book is put aside". They all go to bookstores sporadically, like to look for interesting books and enjoy their calm environment, but do not consider visiting bookstores to be one of their favorite pastimes. Alonso, for example, selected the interview setting because of the quality of the coffee served. He preferred a bakery over the nearby bookstore's coffee shop, which made the researchers suspect that he had little emotional connection with the world of books. In the photo-elicitation exercise, Alonso brought images of product displays, such as food and clothing, and photos of the book exhibition at the bookstore, to argue that the organization of the bookstore is confusing, and comparing books with other product categories. This initially frustrated the researchers, but was essential for structuring the analysis.

Between passionate and indifferent readers, the two opposite extremes of the continuum, some participants display who display a moderate connection with the universe of books. The more passionate the participant, the more emotional and book-driven their responses to offers, and the greater the importance attached to bookstore experiences. The more indifferent the participant, the more rational and environment-driven their responses, and the smaller the importance attached to bookshop experiences. At lunchtime on weekdays, when the store is full of people who work nearby, we see consumers walking slowly between the bookshelves, their eyes fixed and absorbed in reading passages from books; these are the ones who most enjoy reading. Others walk quickly through the bookstore, looking for a place to sit, absorbed by their cell phones; they are the ones who have the least connection with reading. Although everyone is enjoying the experience of the bookstore, their experiences are different from one another and are of different intensity. 
Another personal characteristic that influences the role of the physical store in contemporary retail, combining the physical and virtual environments, is the attachment to materiality. In relation to books, participants with a greater attachment to materiality report tactile appreciation of the object, its shape, weight, type of paper, font and smell, and above all their familiarity with the paper book when reading, and in the store they report the pleasure of being surrounded by books and enjoying the environment. It is as if the materialization of their individuality and values (Ferreira \& Scaraboto, 2016), the extension of their identities (Belk, 1988) and their attachment to the store (Lewicka, 2011) lie not in the singularity of the objects (Kopytoff, 1986) and specific places, but in the whole category. For analysis purposes, we also consider this feature as a continuum, simplifying the complex combination of different variables related to the virtual and physical alternatives of channel and product: preference intensity, effective adoption, reasons for adoption, and value of the experience. We identified participants in different positions. Iracema, who only reads physical books and only buys in physical bookstores, is the extreme example of strong attachment to materiality, while Winston, who reads digital books and buys from online stores, is the extreme example of detachment from materiality. Between these two extremes we find, for example: Melanie, who only reads physical books and buys online; Elizabeth, who prefers physical books, buys online and picks up the book in the physical store; Clarita, who prefers physical books and stores, but occasionally buys a digital book for the price and convenience; and Rubem, who reads physical and digital books, prefers physical stores, but also uses the online channel. With the exception of Iracema, all participants move between the physical and online dimensions to buy and consume books, consider they are different experiences, and say they prefer physical stores and books to digital options.

Figure 1. Tipology - Physical store consumer perception

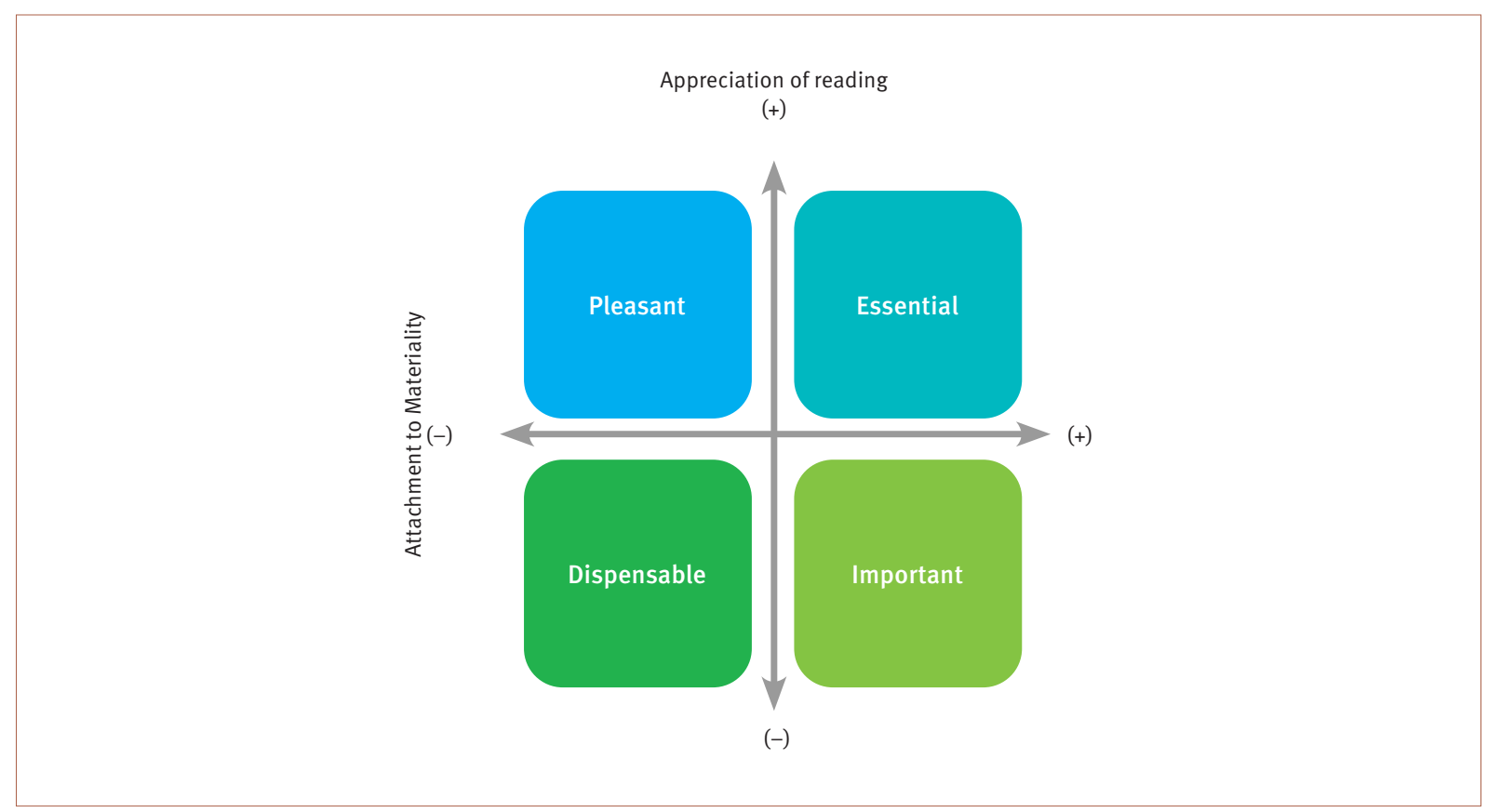

Source: Prepared by the authors.

The combination of an appreciation of reading and attachment to materiality leads to different understandings of the role of physical stores, as shown in Figure 1. Pollyanna and Winston's characteristics make them attribute 
very different degrees of relevance to physical stores; they are essential for Pollyanna and expendable for Winston. In relation to the participants with an ordinary appreciation of reading and a strong attachment to materiality, like Alonso, stores are important. He has little time to read, buys technical books in finance and accounting, always in their physical versions, and is not in the habit of buying over the Internet. In relation to participants like Lucy, with a great appreciation of reading and little attachment to materiality, stores are pleasant and work as showrooms. She prefers physical books but reads e-books and transitions between the physical and digital environments to purchase them, choosing the book in a physical store, researching prices on her cell phone, and buying where she finds the best price. These personal characteristics are not static, and the appreciation of reading can vary with life changes, as is the case with Theodora, who used to be a passionate reader, but today has distanced herself from reading, or Fitz, who recently discovered reading. The attachment to materiality has been decreasing for several participants, such as Emília and Melanie, who now use digital versions of books and stores for convenience, practicality or price.

Academic literature highlights the emotional and subjective nature of the experience (Schmitt, 2009), and our analysis emphasizes the concept of experience being shaped by consumers' stories, values, needs, dreams and fantasies, so being different for each consumer. The study's data show that contexts in which there is a greater emotional involvement provide more attractive cultural resources, resulting in experiences to which consumers find it easier to relate. Below, we outline the four types of bookshop experience identified in the research.

\section{Types of consumer experience}

We established that each consumer undergoes these experiences differently, because specific personal characteristics result in different responses to a company's offers and have an influence on the relevance of a given physical store. We now show the types of experiences that emerge from consumers' interactions with a set of crystallized offers at the store. In this study, we identified four types of bookstore experience: Home Haven, The Magic Portal, Seeking Out and A Place to Shop. We realized that while physical stores provide all four experiences, online bookstores provide only the last two. We now describe the four types of experience emerging from bookstores.

\section{A Place to Shop}

A Place to Shop is the functional experience that occurs in stores in any segment when the consumer has the clear goal of buying quickly. The consumer experience in a bookstore is described in academic literature as hedonic on all occasions, but varying according to the consumer's own mental model, whether creative or functional (Addis, 2016). The data in this study, however, show that the consumer experience in bookstores is dependent on an appreciation of reading, and can be either hedonic or functional. In bookstores, this experience is anchored in objective factors, such as price and practicality, in addition to the delivery time of online bookstores, or the location of the physical bookstore. Winston's visit to the physical bookstore near his home to buy a book as a gift for his mother is an example of the functional experience - A Place to Shop, as he puts it: "In the case of a gift, when you know exactly what you want, the perception that you cannot waste much time in the bookstore is greater. So I go in and say [to the salesperson] 'I want this book', then I quickly buy it and leave."

The A Place to Shop experience takes places frequently in online stores, which offer conveniences that can compensate for the loss of the more significant experiences in physical stores, even for consumers who like to go to a store just to walk around, as Hermione says: "I also buy books online, but I like to go to bookstores to 
shop, for the experience of reading. [...] when I want to buy a specific book and I'm not in a hurry to get it, I buy it on the Internet because l'll receive it at home." This type of experience, represented by images of products from different categories that were brought by Alonso in the photo elicitation exercise, is the most objective of the four that emerge from bookstores.

\section{Seeking Out}

Seeking Out is the experience of consumers who get excited about seeking out a valuable item that is hidden among a group of similar items. The need to select an interesting option from among several books appears in the illustration of a heart and a thorny bush that Mikael produced for the photo elicitation exercise. In the bookstore, the Seeking Out experience originates from the choice of the book and is associated with a hedonic purchase, which provides pleasure (Alba \& Williams, 2013), as Camilo explains: "A hunt is literally a hunt, offering all the pleasure that hunting provides [...]. The whole process of tracking down a book is pleasurable." All participants in the research are in the habit of visiting bookstores to see what's new and to try to find a gem. They use several strategies to select a book, mixing the physical and virtual dimensions; a common strategy on the Internet or in physical stores is to start with a known genre or author and then expand the search. But as Rubem explains, physical stores provide a more organic experience, allowing for unexpected discoveries:

To go from the foreign literature section to the cooking section, I have to walk. When I'm online [...] I always have to know what I want. Here I can walk in without knowing what I really want. So, I don't know what I want, I'm wandering around, l'm thinking. Online you can't wander around.

Some participants, such as Lucy, complement the research on the Internet with a visit to the store, as she explains: "The physical store for me ends up being more for research, so I can see and check the book, see the type of cover it has, what kind of paper it has, what type of editions it has." After choosing the book and still inside the physical store, Lucy uses her cell phone to search for prices and buys it wherever the price is cheapest, thus engaging in a showrooming practice (Verhoef et al., 2007) in which mobile technology gives more power and control to consumers, as foreseen in the academic literature (Labrecque, vor dem Esche, Mathwick, Novak \& Hofacker, 2013).

\section{Home Haven}

Home Haven is the experience provided by a peaceful place, offering a sense of security, familiarity, warmth and shelter against a chaotic outside world. Tistou, for example, describes the shopping mall bookstore he usually visits as a place to decompress, helping relieve the stress of shopping, a feeling reflected in the collage contrasting the busy subway representing the chaos of the outside world, and the bookstore shelves, representing calm and security, which Mikael brought to the photo elicitation exercise. For Lucy, bookstores provide security; having moved to the city two months ago, she spends her free time in a bookstore near her home, in an environment she describes as pleasant, quiet and familiar, where she can stay as if she were at home. For Camilo, bookstores bring a sense of belonging:

[...]it's a peaceful place, a good place to reflect. I usually make bookstores a meeting place. For example: when I'm in São Paulo, I work on Paulista Avenue for several companies. I arrive fifteen minutes earlier, with time to have a coffee at the bookstore, I sit there and read. [...]bookstores have these lounges, these comforting, pleasant places. I feel at home in any bookstore in the world. 
In this type of experience, bookstores take on a role which resembles one's home, an emotional place of well-being (Belk, Seo, \& Li, 2007) that provides comfort and safety (Roster, Ferrari \& Jurkat, 2016). Given that bookstores have a quiet and calm environment, offer protection and the opportunity for relaxation and socialization for the whole community, they are similar to third places (Oldenberg \& Brisset, 1982). However, the academic literature establishes that since they are places where visitors do not prioritize socialization, but enjoy them primarily alone, bookstores are not third places, although the cafes in bookstores can make them nearer to being a third-place (Laing \& Royle, 2013).

\section{The Magic Portal}

The Magic Portal experience is where bookstores are perceived as a passage between the normal world and a magical world inside books, like the rabbit hole into which Alice falls (Carroll, 2018), or the old wardrobe inside which Lucy and her brothers cross over to Narnia (Lewis, 2012). A recurring theme in fantasy literature, portals are a gateway to the unknown, a world where anything can happen, a metaphor for transformation and liminality (Gennep 1960). Since bookstores are a place for books and contain a large number of titles, they function as that place suspended between the everyday world and thousands of possibilities of imaginary worlds, where new knowledge is accessed through reading. The bookstore experience is magical, because it brings consumers closer to transforming powers (Arnould, Price \& Otnes, 1999) by allowing them access to books, with fetish aspects - an object with extraordinary powers that transforms and expands the sense of self (Fernandez \& Ladowicka 2011) through knowledge and imagination.

For Emmanuel, a bookstore's appeal is linked to the variety of books it offers: "[It has] options in terms of content, images, stories, interesting things in general. It's a place where you will find several types of books, of all colors, sizes, finishes, [...] relaxing books, serious books, decorative books, philosophical books. It has everything."

The transformative power of a book is reflected in Prince's words: "you also disconnect a little from the real world, assuming and entering into another one with the character to reach another point of view"; in Melanie's: "there can be a journey, containing feelings, thoughts [...] it takes you to places you would never know inside someone's imagination"; and Theodora's: “I believe that books and literature raise the question of dreaming, of imagining things that do not exist yet, but that can exist." This experience is represented by an image from the film "Intersection" that Lucy selected, showing an infinity of spaces and times with a technological feel, and the image selected by Mikael of a boy entering into an environment lit by a portal.

\section{DISCUSSION}

Our study investigates consumer experience in retail under dematerialization to reveal more details about the role of physical stores. The consumer experience concept is anchored in the idea of co-creation and defines that experience emerges from consumer responses to company offers that are crystallized at the points of contact (Lemon \& Vehoef, 2016; Thompson, 2004). Our study, which was carried out in the context of bookstores, finds that each consumer responds to offers differently, and establishes that consumers' contribution to co-creating the experience depends on their personal characteristics, so that each consumer has an individualized experience. Below, we detail the research findings. 


\section{Individualized Experience}

Literature establishes that the concept of consumer experience focuses on consumers' responses to company offerings (Lemon \& Verhoef, 2016), emphasizing that the experience is not controlled by companies (Prahalad \& Ramaswamy, 2004) because it only takes place when a consumer enjoys such offerings. Therefore, experiences emerge from the interaction, at the points of contact, between the consumer and the company, and are co-created by both. In academic literature, from a consumer-centered perspective retail is a source of multiple cultural resources that are mobilized by consumers to carry out life projects, combining these potential resources with their own resources, such as traditions and values (Thompson, 2004). As each consumer has unique projects and resources, the experience that emerges at the points of contact from the interaction between the company and the consumer is individualized.

\section{Relevance of the store depends on the meanings of the experience}

Since the experience is individualized for each consumer and emerges from interactions at the points of contact, each consumer undergoes a unique experience, and the same consumer may have different experiences at different contact points and situations. Although the responses of each consumer may vary with different interactions at the same point of contact, the meanings attributed to their consumption experiences at each point of contact tend to be similar. The attribution and transfer of meanings by consumers take place when they reflect on the experiences they had and select the resources from the offers in the market that most contribute to the realization of their projects (Thompson, 2004). We concluded by identifying during data analysis the patterns by which personal characteristics define the meanings attributed and the relevance of the point of contact. In the bookstore, we found that the relevance of the physical store increases when consumers are fond of reading and attached to materiality. Many of the survey participants state that they have only recently started shopping online and consuming digital books. It is reasonable to imagine, therefore, that as consumer familiarity with digital consumption increases and companies invest to make the virtual dimension more immersive and interesting, such as in the online spaces studied by Denegri-Knott and Molesworth (2010), the perception of the relevance of physical stores will change.

\section{Four types of experience in the physical store and only two in the online store}

We identified four types of experience in the interaction of consumers with sales channels in our study: Home Haven (Refúgio do Lar), The Magic Portal (Portal da Magia), Seeking Out (Garimpo) and A Place to Shop (Lugar de Compras). Academic literature establishes that a consumer's mental model defines the nature of the experience, which is hedonic if conducted by consumers whose mental model is curiosity, leveraged by interactions with people, and functional if driven by people with planning as a mental model, leveraged by interactions with technology (Addis, 2016). Our study differs from this understanding, suggesting that the definition of the bookstore experience as hedonic or functional is, primarily, a function of the personal characteristics of the consumer, and the mental model at the time of purchase is of secondary importance.

The A Place to Shop and Seeking Out experiences are related to the search and acquisition of products and occur in different settings on the shopping journey; just in the physical store, just in the online store, or in a combination of the two. Academic literature describes consumer empowerment through technology (Labrecque et al., 2013, Verhoef et al., 2017), and our research confirms that there is more control and security in a purchase 
that combines the physical and virtual dimensions, especially when there is concomitant engagement with both channels at the time of purchase, and when the online search is carried out in the physical store. A Place to Shop and Seeking Out are control experiences.

The Home Haven and The Magic Portal experiences only occur in the physical store, and are anchored in the store's atmosphere; the presence of books and contact with salespeople are hedonic and evoke fun, feelings and fantasy (Holbrook \& Hirschman, 1982). In the academic literature, physical bookstores are considered to be unusual, and to have certain third place characteristics (Addis, 2016; Laing \& Royle, 2013). Our study also identifies elements in the bookstore that make up the concept of home, such as quietness, calmness, wellbeing, protection, security and socialization (Belk et al., 2007; Oldenberg \& Brisset, 1982; Roster et al., 2016), as expressed in the Home Haven experience. The Magic Portal experience, which is related to the transformative power of reading, is anchored in books, which are magical objects that allow contact with alternative realities that provide pleasure and learning. The habit of taking children to visit bookstores in order to encourage reading, which is a morally valued practice, evokes this transformative power that originates not in the forces of nature (Arnould et al., 1999), but in the forces of human knowledge and creativity. Home Haven and The Magic Portal are experiences of shelter and transcendence.

\section{Contributions, limitations and directions}

Our study contributes to the academic literature on consumer experience, and expands the notion of the co-creation of the experience by establishing that the experience of each consumer is unique. It also contributes to the retail literature, establishing that the relevance of the store is determined by the personal characteristics of the consumer, and empirically confirming that engagement with both the physical and online channels with regard to product selection and purchase leads to consumer empowerment. Understanding the factors that determine the relevance of the physical store can contribute to integrated retail management, providing support for adjusting the store model and the offers to fit the desired customer profile. It can help define the investment in data and design technologies that individualize the physical store experience (Linzbach et al., 2019) and improve the online store experience (Denegri-Knott \& Molesworth, 2010; Mardon \& Belk, 2018).

As is typical of qualitative research, our research findings cannot be generalized, but rather are inherent to bookstores, a segment that is particularly affected by digital transformation and provides unique experiences because books are highly symbolic. We believe, however, that the observations generated by this study may offer clues about the experience of contemporary consumption in general, since it seems to us that the intensity of the attachment to the material world is important for determining the relevance of physical stores in any segment. Stores for products in any segment can provide experiences similar to the Seeking Out and The Magic Portal ones, if there is a special appreciation of the category of products sold. Clothing, accessories and makeup all have a transcendent power that makes consumers feel safer and more attractive, while sports equipment can charm consumers into becoming champions, and cooking accessories can magically transform consumers into kitchen artists. An opportunity for future research is to investigate whether the same criteria for determining the relevance of physical stores can be applied to other segments, and to check for variations in product categories at different distances from the extended self (Belk, 1988, 2014).

Our study shows that changes in bookstores are inexorable. With the dematerialization of consumption, physical stores, which used to be the main point of contact between companies and consumers, are now just 
another point of contact among several others. To survive, retailers need to offer meaningful experiences by consistently integrating digital and physical channels throughout the shopping journey. This study was developed with the hope that books will continue to delight readers, that the various experiences in bookstores will resonate with consumers, and physical bookstores will resist.

\section{NOTE}

This article was presented at the $2^{\text {nd }}$ International Social Networks Conference in 2019, promoted by the Center for Retail Excellence, FGV EAESP Business Administration School of São Paulo.

\section{REFERENCES}

Addis, M. (2016). Understanding the customer journey to create excellent customer experiences in bookshops. International Journal of Marketing Studies, 8(4), 20. doi:10.5539/ijms.v8n4p20

Addis, M., \& Holbrook, M. (2001). On the conceptual link between mass customisation and experiential consumption: An explosion of subjectivity. Journal of Consumer Behaviour, 1(1), 50-66. doi:10.1002/cb.53

Alba, J., \& Williams, E. (2013). Pleasure principles: A review of research on hedonic consumption. Journal of Consumer Psychology, 23(1), 2-18. doi: 10.1016/j.jcps.2012.07.003

Almeida, C. (2017, julho 6). Experiência não paga a conta. Exame. Retrieved fromhttps://exame.abril.com.br/negocios/herzda-cultura-experiencia-nao-paga-conta/

Arnould, E. (2005) Animating the big middle. Journal of Retailing, 81(2), 89-96. doi:10.1016/j.jretai.2005.03.001

Arnould, E., Price, L., \& Otnes, C. (1999). Making magic consumption: A study of white-water river rafting. Journal of Contemporary Ethnography, 28(1), 33-68. doi:10.1177/089124199129023361

Arsel, Z. (2017). Asking questions with reflexive focus: A tutorial on designing and conducting interviews. Journal of Consumer Research, 44(4), 939-948. doi:10.1093/jcr/ucx096

Atasoy, O., \& Morewedge, C. K. (2018). Digital goods are valued less than physical goods. Journal of Consumer Research, 44(6), 1343-1357. doi:10.1093/jcr/ucx102

Aubrey, C., \& Judge, D. (2012). Re-imagine retail: Why store innovation is key to a brand's growth in the 'new normal', digitally-connected and transparent world. Journal of brand strategy, 1(1), 31-39.

Babin, B., Darden, W., \& Griffin, M. (1994). Work and/or fun: Measuring hedonic and utilitarian shopping value. Journal of Consumer Research, 20(4), 644-656. doi:10.1086/209376

Bardhi, F., \& Eckhardt, G. M. (2012). Access-based consumption: The case of car sharing. Journal of Consumer Research, 39(4), 881-898. doi: $10.1086 / 666376$
Bardhi, F., \& Eckhardt, G. M. (2017). Liquid consumption. Journal of Consumer Research, 44(3), 582-597. doi:10.1093/jcr/ucx050

Belk, R. (1988). Possessions and the extended self. Journal of Consumer Research, 15(2), 139-168. doi:10.1086/209154

Belk, R. (2014). You are what you can access: Sharing and collaborative consumption online. Journal of Business Research, 67(8), 1595-1600. doi:10.1016/j.jbusres.2013.10.001

Belk, R., Seo, Y., \& Li, E. (2007). Dirty little secret: Home chaos and professional organizers. Consumption Markets \& Culture, 10(2), 133-140. doi: 10.1080/10253860701256208

Carroll, L. (2018). Alice no País das Maravilhas. São Paulo, SP: Sesi-SP.

Carù, A., \& Cova, B. (2003). Revisiting consumption experience: A more humble but complete view of the concept. Marketing Theory, 3(2), 267-286. doi:10.1177/14705931030032004

Coffman, C. (2018, June 19) Shops aren't for shopping anymore. The Atlantic. Retrieved from https://www.theatlantic.com/ TECHNOLOGY/ARCHIVE/2018/06/SHOPS-ARENT-FORSHOPPING-ANYMORE/563054/?UTM_SOURCE=ATLFB

Corkery, M. (2018, September 3) Hard lessons (Thanks Amazon) breath new life into retail stores. The New York Times. Retrieved from https://www.nytimes.com/2018/09/03/ business/retail-walmart-amazon-economy.html

DeLanda, M. (2006). A new philosophy of society: Assemblage theory and social complexity. London, UK: Continuum.

Denegri-Knott, J., \& Molesworth, M. (2010). Concepts and practices of digital virtual consumption. Consumption, Markets and Culture, 13(2), 109-132. doi:10.1080/10253860903562130

Denegri-Knott, J., Watkins, R., \& Wood, J. (2013). Transforming digital goods into meaningful possessions. Digital Virtual Consumption, 23(76), 83-98. 10.4324/9780203114834

Exame. (2018, outubro 25). Livraria Cultura pede recuperação judicial em meio à crise do mercado. Retrieved fromhttps:// exame.abril.com.br/negocios/livraria-cultura-pederecuperacao-judicial-em-meio-a-crise-do-mercado/ 
Fernandez, K., \& Lastovicka, J. (2011). Making magic: Fetishes in contemporary consumption. Journal of Consumer Research, 38(2), 278-299. doi:10.1086/659079

Ferreira, M., \& Scaraboto, D. (2016). "My plastic dreams": Towards an extended understanding of materiality and the shaping of consumer identities. Journal of Business Research, 69(1), 191-207. doi:10.1016/j.jbusres.2015.07.032

Gennep, A. van. (1960) The rites of passage (M. B. Vizedom \& G. L. Caffe, Trans.). London, UK: Routledge and Kegan Paul.

Gensler, S., Neslin, S., \& Verhoef, P. (2017). The showrooming phenomenon: It's more than justabout price.JournalofInteractive Marketing, 38, 29-43. doi:10.1016/j.intmar.2017.01.003

Gibbs, G. R. (2008). Analysing qualitative data: The Sage qualitative research kit. Newbury Park, USA: Sage.

Gill, M. J. (2014). The possibilities of phenomenology for organizational research. Organizational Research Methods, 17(2), 118-137. doi:10.1177/1094428113518348

Giovanelli, C. (2016, março 21). Cultura fecha 2 de suas 4 lojas no Conjunto Nacional. Veja SP. 21/03/2016. Retrieved fromhttps://vejasp.abril.com.br/consumo/livraria-culturaconjunto-nacional-fechou-lojas/

Hirschman, E., \& Horlbrook, M. (1982). Hedonic consumption: Emerging concepts, methods and propositions. The Journal of Marketing, 46(3), 92-101. doi:10.1177/002224298204600314

Hoffman, D. L., \& Novak, T. P. (2017). Consumer and object experience in the internet of things: An assemblage theory approach. Journal of Consumer Research, 44(6), 1178-1204. doi:10.1093/jcr/ucx105

Holbrook, M. (2018). Essay on the origins, development, and future of the consumption experience as a concept in marketing and consumer research. Qualitative Market Research: An International Journal, 21(4), 421-444. doi: 10.118/QMR-04-2018-0041

Holbrook, M., \& Hirschman, E. (1982, September). The experiential aspects of consumption: Consumer fantasies, feelings, and fun. Journal of Consumer Research, 9, 132-140. doi:10.1086/208906

Holbrook, M. B. (2000). The millennial consumer in the texts of our times: Experience and entertainment. Journal of Macromarketing, 20(2), 178-192. doi:10.1093/jcr/ucx105

Kopytoff, I. (1986). The cultural biography of things: Commoditization as process. In A. Appadurai, The social life of things: Commodities in cultural perspective (pp. 64-91). Cambridge, UK: Cambridge University Press.

Kozinets, R. (2019). Consuming technocultures: An extended JCR curation. Journal of Consumer Research, 46(3), 620-627. doi:10.1093/jcr/uczo34

Kozinets, R., Patterson A., \& Ashman, R. (2017). Networks of desire: How technology increases our passion to consume. Journal of Consumer Research, 43(5), 659-682. doi:10.1093/ jcr/ucwo61

Labrecque, L., Esche, J. vor dem, Mathwick, C., Novak, T., \& Hofacker, C. (2013). Consumer power: Evolution in the digital age. Journal of Interactive Marketing, 27(4), 257-269. doi:10.1016/j.intmar.2013.09.002
Laing, A., \& Royle, J. (2013). Examining chain bookshops in the context of "third place". International Journal of Retail \& Distribution Management, 41(1), 27-44. doi:10.1108/09590551311288157

Lehdonvirta, V. (2012). A history of the digitalization of consumer culture: From Amazon through Pirate Bay to FarmVille. Digital virtual consumption (pp. 11-28). New York, USA: Routledge.

Lemon, K., \& Verhoef, P. (2016). Understanding customer experience throughout the customer journey. Journal of Marketing, 8o(6), 69-96. doi:10.1509/jm.15.0420

Lewicka, M. (2011). Place attachment: How far have we come in the last 40 years? Journal of Environmental Psychology, 31(3), 207-230. doi:10.1016/j.jenvp.2010.10.001

Lewis, C. S. (2012). As crônicas de Nárnia, São Paulo, SP: Martins Fontes.

Linzbach, P., Inman, J. J., \& Nikolova, H. (2019). E-Commerce in a physical store: Which retailing technologies add real value? NIM Marketing Intelligence Review, 11(1), 42-47. Retrieved fromhttps://www.proquest.com/ openview/cbo379f1589a5bo62951ec75661819aa/1?pqorigsite $=$ gscholar $\& \mathrm{cbl}=756365$

Livraria Cultura. (2017). Quem somos. Retrieved fromhttps:// www.livrariacultura.com.br/quem-somos

Magaudda, P. (2011). When materiality 'bites back': Digital music consumption practices in the age of dematerialization. Journal of Consumer Culture, 11(1), 15-36. doi:10.1177/1469540510390499

Mardon, R., \& Belk, R. (2018). Materializing digital collecting: An extended view of digital materiality. Marketing Theory, 18(4), 543-570. doi:10.1177/1470593118767725

Melo, A. (2018, junho 13). Cultura fecha Fnac de Pinheiros, em SP, primeira loja da rede no país. Valor Econômico. Retrieved fromhttps://www.valor.com.br/empresas/5593585/culturafecha-fnac-de-pinheiros-em-sp-primeira-loja-da-rede-no-pais

Oldenburg, R., \& Brissett, D. (1982). The third place. Qualitative Sociology, 5(4), 265-284. doi:10.1007/BFoog86754

Pine, B., \& Gilmore, J. (1998). Welcome to the experience economy. Harvard Business Review, 76, 97-105. Retrieved from https://is.muni.cz/el/econ/jaro2020/ MKR_PRCR/98252981/Pine_Gilmore_Welcome_to_the_ Experience Economy.pdf

Pine, B., \& Gilmore, J. (1999). The experience economy: Work is theatre \& every business a stage. Cambridge, UK: Harvard Business Press.

Prahalad, C. K., \& Ramaswamy, V. (2004). Co-creation experiences: The next practice in value creation. Journal of Interactive Marketing, 18(3), 5-14. doi:10.1002/dir.20015

Roster, C., Ferrari, J., \& Jurkat, M. (2016). The dark side of home: Assessing possession 'clutter' on subjective wellbeing. Journal of Environmental Psychology, 46, 32-41. doi:10.1016/jenvp.2016.03.003

Rushe, D. (2017, July 23). Big, bold ... and broken: Is the US shopping mall in a fatal decline? The Guardian. Retrieved from https://www.theguardian.com/us-news/2017/jul/22/ mall-of-america-minnesota-retail-anniversary 
Schmitt, B. (2009) The concept of brand experience. Journal of Brand Management, 16, 417-419. doi:10.1057/bm.2009.5

Schmitt, B. (2011). Experience marketing: Concepts, frameworks and consumer insights. Foundations and Trends ${ }^{\circledR}$ in Marketing, 5(2), 55-112. doi:10.1561/1700000027

Schmitt, B., Brakus, J., \& Zarantonello, L. (2015). From experiential psychology to consumer experience. Journal of Consumer Psychology, 25(1), 166-171. doi:10.1016/jcps.2014.09.001

Schmitt, B., Rogers, D., \& Vrostsos, K. (2004). There's no business that's not show business: Marketing in an experience culture. New Jersey, USA: Financial Times Press.

Shankar, V., Inman, J., Mantrala, M., Kelley, E., \& Rizley, R. (2011). Innovations in shopper marketing: Current insights and future research issues. Journal of Retailing, 87, S29-S42. doi:10.1016/j.jretai.2011.04.0007

Sherry, J. (1998). Understanding markets as places: An introduction to servicescapes. In J. Sherry (Ed.), Servicescapes: The concept of place in contemporary markets (pp. 1-24). Chicago, USA: NTC.

Smith, J., Flowers, P., \& Larkin, M. (2009). Interpretative phenomenological analysis: Theory, method and research. London, UK: Sage.

Thompson, C., Locander, W., \& Pollio, H. (1989). Putting consumer experience back into consumer research: The philosophy and method of existential-phenomenology. Journal of Consumer Research, 16(2), 133-146. doi:10.1086/209203
Thompson, C. J. (2004). Marketplace mythology and discourses of power. Journal of Consumer Research, 31(1), 162-180. doi:10.1086/383432

Tracy, S. J. (2010). Qualitative quality: Eight "big-tent" criteria for excellent qualitative research. Qualitative Inquiry, 16(10), 837-851. doi:10.1177/1077800410383121

Verhoef, P., Kannan, P., \& Inman, J. (2015). From Multi-channel retailing to omni-channel retailing: Introduction to the special issue on multi-channel retailing, Journal of Retailing, 91(2), 174-181. doi:10.1016/j.jretai.2015.02.005

Verhoef, P., Neslin, S., \& Vroomen, B. (2007). Multichannel customer management: Understanding the researchshopper phenomenon. International Journal of Research in Marketing,24(2),129-148. doi:10.1016/j.ijresmar.2006.11.002

Verhoef, P., Stephen, A., Kannan, P., Luo, X., Abhishek, V., Andrews, M., ... Hu, M. M. (2017). Consumer connectivity in a complex, technology-enabled, and mobile-oriented world with smart products. Journal of Interactive Marketing, 40, 1-8. doi:10.1016/j.intmar.2017.06.001

Wallendorf, M., \& Belk, R. W. (1989). Assessing trustworthiness in naturalistic consumer research. In E. Hirschman (Ed.), Interpretative consumer research (ACR Special Volumes, pp. 69-84). Provo, USA: Association for Consumer Research.

Wallendorf, M., \& Brucks, M. (1993). Introspection in consumer research: Implementation and implications. Journal of Consumer Research, 20(3), 339-359. doi:10.1086/209354

\section{AUTHORS’ CONTRIBUTIONS}

Maria Silvia Moliterno Pena and Eliane Pereira Zamith Brito worked on the conceptualization and theoreticalmethodological approach. The theoretical review was conducted by Maria Silvia Moliterno Pena. Data collection was coordinated by Maria Silvia Moliterno Pena. Data analysis included Maria Silvia Moliterno Pena e Eliane Pereira Zamith Brito. Maria Silvia Moliterno Pena and Eliane Pereira Zamith Brito worked together in the writing and final revision of the manuscript. 